UDC 514.18

\title{
MODELS OF MOTION OF A PARTICLE ON ROUGH NON-LINEAR SURFACES OF THE 2ND ORDER IN THE FUNCTION OF TIME
}

\author{
A.V. Nesvidomin, PhD \\ National University of Life and Environmental Sciences of Ukraine \\ E-mail: a.nesvidomin@gmail.com
}

\begin{abstract}
The purpose of the study is the development of Maple-model of motion of a particle on a non-linear surfaces of the 2 nd order in the function of time.

A computational experiment was conducted to study the trajectory-kinematic properties of the motion of a particle on a non-linear surfaces of the 2 nd order in the function of time.

On the example of forming the laws of motion of a particle on rough nonlinear surfaces in a computer algebra Maple environment, the possibility is shown that the sequence of cumbersome analytic transformations can not be elaborated at all. In this case, the user of the model of studying the motion of a particle on a rough surface is enough to only set the initial conditions for the particle sinking and to form a set of trajectory-kinematic characteristics studied.
\end{abstract}

Key words: accompanying triedrone, material point, non-linear surfaces, trajectory of motion

Topicality. In many technological processes of agricultural production there is a movement of material particles on a rough non-linear surfaces of the 2 nd order. Knowledge of the patterns of motion of a particle (as a material point) by a rough plane in three-dimensional space allows us to calculate the structural and kinematic parameters of the working bodies [1].

Analysis of recent research and publications. An analytical derivation of the motion of a particle on rough non-linear surfaces of the 2 nd order. is reduced to the compilation of a system of differential equations of the second order, the dependence of which is the trajectory of the particle, its velocity, acceleration, the length of the traversed path, the force of the normal reaction, the time of movement to it stops and other trajectory-kinematic characteristics. The sequence of analytic transformations 
and methods for solving the derivation of a system of differential equations is quite labor-intensive [2].

Computer modeling of motion of a particle on a rough non-linear surfaces of the 2nd order allows to discard bulky analytical transformations carried out by a scientist and provide him with a convenient dialogue mode for performing necessary computational experiments on particle motion analysis under different initial conditions of its throwing [3].

The purpose of the study is the development of Mapple-a model of motion of a particle on rough non-linear surfaces of the 2 nd order.

Materials and methods of research. In the article, we give only isolated results of computational experiments on the study of trajectory-kinematic characteristics of the motion of a particle on rough non-linear surfaces of the 2 nd order - the sphere, ellipsoid, paraboloid, and two-cavity hyperboloid of rotation (extended studies of each surface occupy a fairly large volume of textual and graphic information). All analytical calculations, since the problem of form and position non-linear surface rotation $2 \mathrm{nd}$ order system Cartesian coordinate Oxyz, sequence forming law of motion of the particles on the surface depending on the position of its axis (vertical, horizontal, inclined) in space, the choice of the studied characteristics in depending on the starting conditions of the particle throwing, all this is represented in the corresponding maple models (see geometry.com.ua), the names of which are given below.

\section{Research results and their discussion.}

\section{Sphere_t - model of motion of a particle in a sphere}

The motion of a particle in a rough sphere does not depend on its position. If the particle is thrown at the same initial velocity $V_{o}$ from different places on the meridian of the spheres in one direction $\alpha_{o}$, for example, the parallels, it is clear that their trajectories $r(t)$ are approaching the lower pole (Fig. 1, a). The fastest part will be stopped, which was the lowest. For the lowest particle on the sphere at the beginning 
of its movement, the force of the normal reaction $F_{N}(t)$ is greatest due to the greater curvature of the trajectory.

Turn the sphere at an angle $90^{\circ}$ around the $O x$ axis (Fig. 1, b). We cast throw with the same velocity $V_{o}$ but in different directions $\alpha_{o}=0^{\circ}, 45^{\circ}, 0^{\circ}, 135^{\circ}$. The particle is thrown up parallel to $\alpha_{\circ}=90^{\circ}$, will break off from the surface through the time interval $t \cong 0.4$, the particles are thrown at angles $\alpha_{\circ}=45^{\circ}$ and $\alpha_{\circ}=135^{\circ}$ (at different poles), have symmetrical trajectories and the same kinematic and dynamic characteristics (graphs of speed and normal reaction coincide).

Ellipsoid_t - Model of motion of a particle in an ellipsoid of rotation

In fig. 1 shows the image of the trajectories and graphs of the velocity $V(t)$ and the normal reaction $F_{N}(t)$ of the moving particle on the inner surface of the ellipsoid of rotation, depending on the angle of the throw $\alpha_{\circ}=0^{\circ}, 45^{\circ}, 90^{\circ}, 135^{\circ}$ at its initial position $u_{o}=\pi, v_{o}=-\pi / 6$, initial velocity $V_{o}=4 \mathrm{M} / \mathrm{c}$ and coefficient of friction $f$ $=0.3$. It is clear that the particles in a closed space of the ellipsoid of rotation (Fig. 1, c of the surface of the surface) stop at the bottom of the graphs of velocities $V(t)$, this will begin to occur over time $t \approx 3.5$ and at the time of their stop, the normal reaction $F_{N}(t)$ is approaching $F_{N}=m g$.

The particles thrown from different surfaces of the surface of the ellipsoid of rotation behave in the same way as on the sphere, in particular, their trajectories $r(t)$ will be directed to the bottom, but with a greater amplitude at the velocity $V(t)$ and the normal reaction $F_{N}(t)$ (Fig. 1, d).

\section{Paraboloid_t - Model of particle movement on a paraboloid of rotation}

In Fig. 2? a we present the trajectories $r(t)$ of the particles and graphs of velocity $V(t)$ at different angles of the throw $\alpha_{\circ}=0^{\circ}, 45^{\circ}, 90^{\circ}, 135^{\circ}$, its initial position $u_{o}=\pi, v_{o}=2$, the initial velocity $V_{o}=4$, the coefficient of friction $f=0.3$, the form parameter $a=0.4$. You can see that the trajectory passes at the vertex of the paraboloid, and only the angle of the throw $\alpha_{\circ}=0^{\circ}$ and $180^{\circ}$ the particle will fall to the top. Graphs of velocity V (t) of particles zigzag-like decrease to zero, which means their stop in the vicinity of the top of the paraboloid. The particle that is thrown closest 
to the vertex of the paraboloid at an angle $\alpha_{o}=135^{\circ}$ - at a time interval $t \leq 2.1 \mathrm{~s}$ will stop the fastest. If you throw particles in one direction, for example $\alpha_{o}=90^{\circ}$ - along parallel, but with different initial velocities $V_{o}=2,4,6,8$, then the fastest stop will be a particle with the lowest initial velocity $V_{o}=2$ - this will occur over time $t \cong 2.9 \mathrm{sec}$. The nature of the motion, depending on the friction coefficient $f=0.1,0.2,0.3,0.4$ of particles at a constant angle $\alpha_{o}=90^{\circ}$ indicates that the larger the coefficient of friction $f$, the faster the particle will approach the top of the paraboloid of rotation.

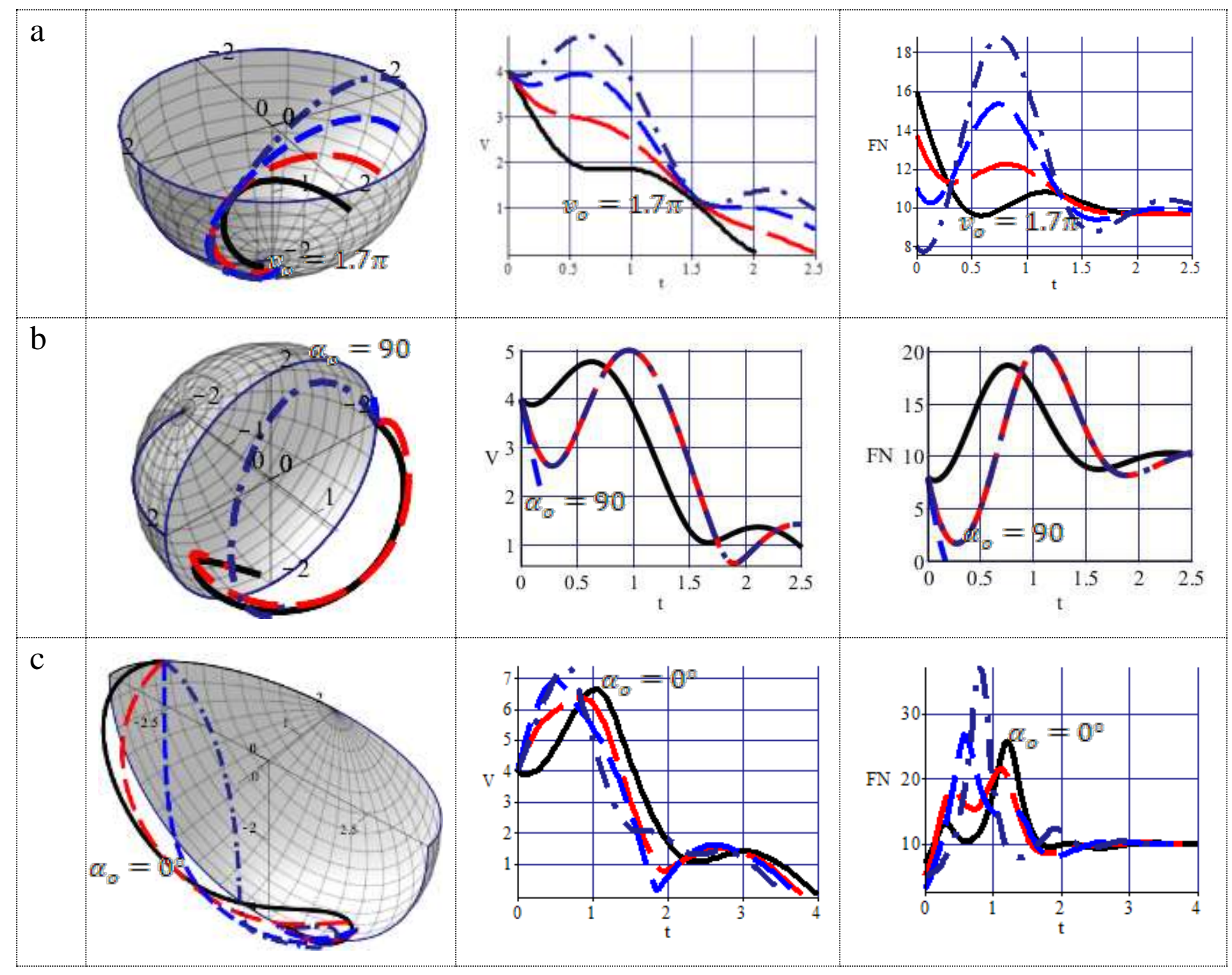



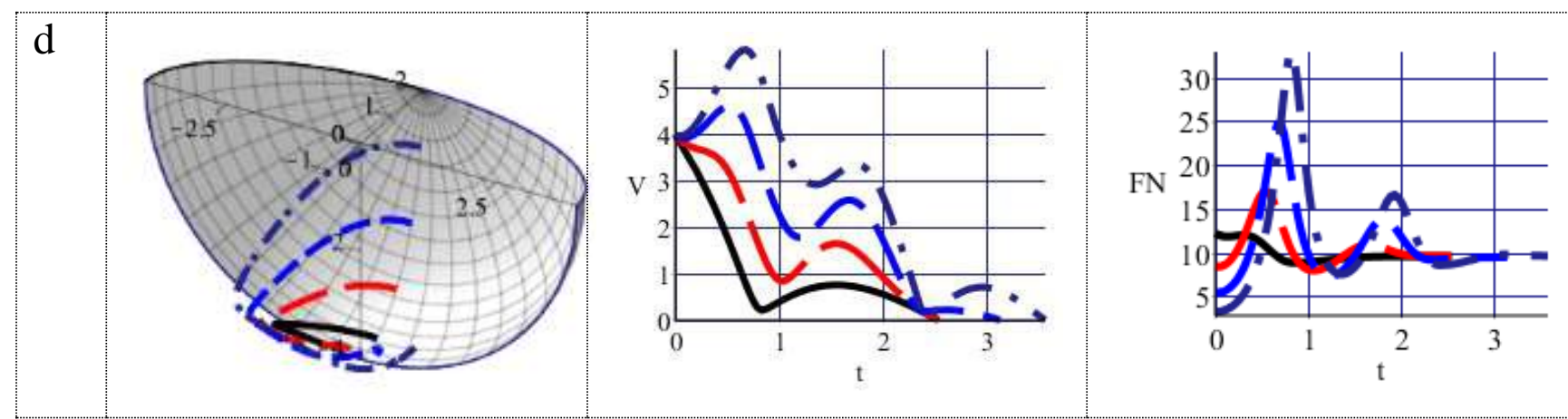

Fig.1 Trajectory-kinematic characteristics of the motion of a particle on the rough interior surfaces of the sphere and the ellipsoid

Hyperboloid2_t - Model of motion of a particle in a two-cavity hyperboloid of rotation

Let the parameters of the form $a$ and $b$ of the generic hyperbolic of the two-cavity hyperboloid of the rotation equate to form $a=1$ and $b=2$ (Fig. 2, b). Since the ratio $\frac{a}{b}>f=0.3$, then the moving particles under any other initial conditions will not stop on the surface - the graphs of velocity $V(t)$ increase. If the parameters of the form of generative hyperbole set $a=1$ and $b=4\left(\frac{a}{b}<f=0.3\right)$, espectively, then all particles will stop on the surface - graphs of velocity $V(t)$ fall to zero. So particles with coefficients of friction $f=0.1,0.2$ with $\alpha_{o}=90^{\circ}$ and $V_{o}=4 \mathrm{M} / \mathrm{c}$ will not stop on the surface, and with coefficients of friction $f=0.3,0.4$ stop on the surface.

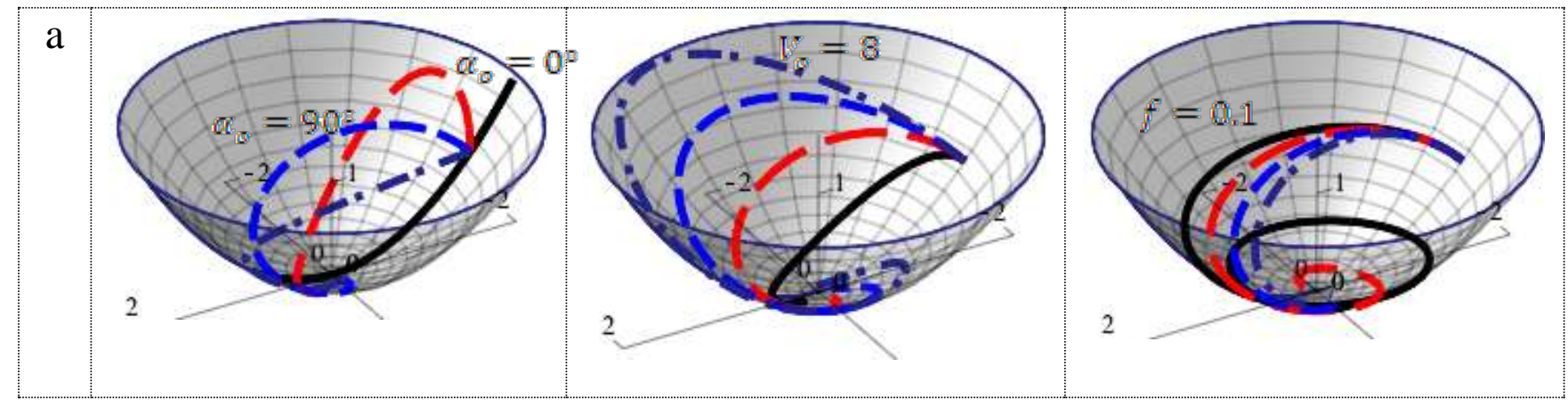




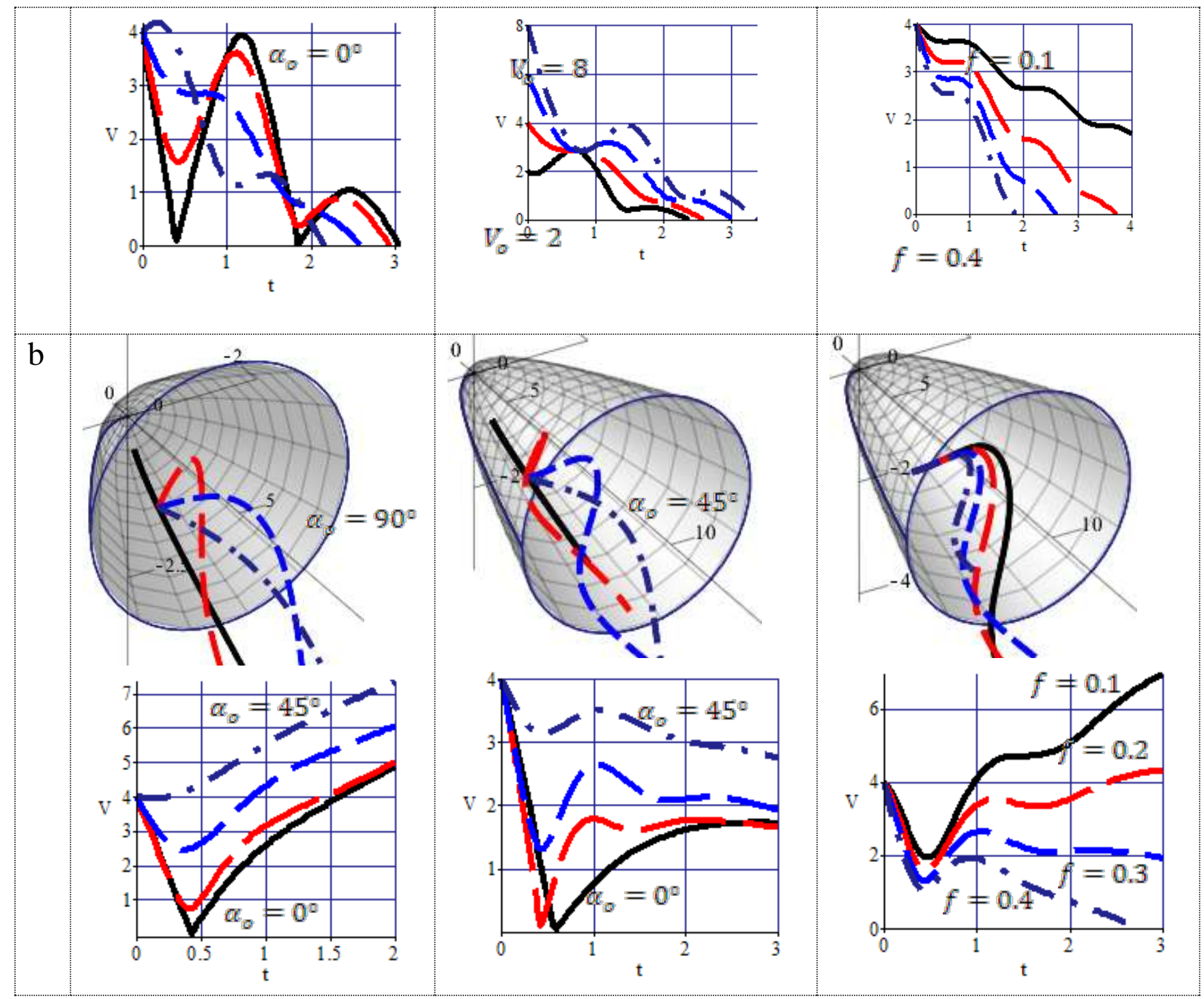

Fig.2 Trajectory-kinematic characteristics of the motion of a particle on rough internal surfaces of a paraboloid and a two-cavity hyperboloid of rotation

Conclusions and perspectives. On the example of forming the laws of motion of a particle on rough nonlinear surfaces in a computer algebra Maple environment, the possibility is shown that the sequence of cumbersome analytic transformations can not be elaborated at all. In this case, the user of the model of studying the motion of a particle on a rough surface is enough to only set the initial conditions for the particle sinking and to form a set of trajectory-kinematic characteristics studied. 
It is supposed to supplement the developed computer models of motion of a particle on rough surfaces of the 2 nd order by means of interactive search of combinations from the initial conditions of a particle sink to provide predefined trajectory and kinematic characteristics of its motion - to solve the inverse problem.

\section{List of references}

1. Адамчук В. В. Теория центробежных рабочих органов машин для внесения минеральных удобрений: монография / В. В. Адамчук. - К.: Аграрна наука, 2010. - $178 \mathrm{c}$.

2. Пилипака C. Ф. Кінематична інтерпретація руху супровідних тригранників Френе і Дарбу через внутрішні параметри кривих / С. Ф. Пилипака // Науковий вісник НАУ. - 1998. - Вип.4. - С.143-146.

3. Пилипака С. Ф. Моделювання руху частинки по шорсткій поверхні параболоїда обертання / С. Ф. Пилипака, А. В. Несвідомін // Прикл. геом. та інж. граф. - К.: КНУБА, 2012. - Вип.89. - С.39-44.

\section{References}

1. Adamchuk, V.V. (2010). Teoriya tsentrobezhnykh rabochikh organov mashin dlya vneseniya mineral'nykh udobreniy [Theory of centrifugal working bodies of machines for the application of mineral fertilizers]. Kiyv.: Ahrarna nauka, 178.

2. Pylypaka, S. F. (1998). Kinematychna interpretatsiia rukhu suprovidnykh tryhrannykiv Frene i Darbu cherez vnutrishni parametry kryvykh [Kinematical interpretation of the motion of the accompanying Fresnel and Darboux triangles through the internal parameters of the curves]. Naukovyi visnyk NAU, 4, 143-146.

3. Pylypaka, S. F., Nesvidomin, A. V. (2012). Modeliuvannia rukhu chastynky po shorstkii poverkhni paraboloida obertannia [Modeling the motion of a particle on a rough surface of a paraboloid of rotation] Prykl. heom. ta inzh. hraf., 89, 39-44.

\section{МОДЕЛЮВАННЯ РУХУ ЧАСТИНКИ ПО ШОРСТКИХ НЕЛІНІЙЧАТИХ ПОВЕРХНЯХ 2-ГО ПОРЯДКУ У ФУНКЦІї ЧАСУ}

\section{А. В. Несвідомін}

Анотація. Метою дослідження була розробка Mapple-моделі руху частинки по шорстких нелінійчатих поверхнях 2-го порядку у функиії часу.

Був проведений обчислювальний експеримент для вивчення траєкторнокінематичних властивостей руху частинки на нелінійних поверхнях 2-го порядку в функиії часу.

На прикладі формування законів руху частинки по шорстких нелінійчатих поверхнях в середовищі комп'ютерної алгебри Maple показано можливість взагалі не унаочнювати послідовність громіздких аналітичних перетворень. У иьому випадку користувачу моделі дослідження руху частинки по шорсткій 
"Енергетика і автоматика", №4, 2018 р.

поверхні достатньо тільки задавати вихідні умови кидання частинки та формувати набір досліджуваних траєкторно-кінематичних характеристик.

Ключові слова: супровідний тригранник, матеріальна точка, нелінійні поверхні, траєкторія руху

\section{МОДЕЛИРОВАНИЕ ДВИЖЕНИЯ ЧАСТИЦЫ ПО ШЕРОХОВАТЫХ НЕЛИНЕЙЧАТЫХ ПОВЕРХНОСТЯХ 2-ГО ПОРЯДКА В ФУНКЦИИ ВРЕМЕНИ}

А. В. Несвидомин

Аннотация. Целью исследования была разработка Mapple-модели движения частищы по шероховатых нелинейчатых поверхностях 2-го порядка в функиии времени.

Был проведен вычислительный эксперимент для изучения траекторнокинематических свойств движения частииы на нелинейных поверхностях 2-го порядка в функиии времени.

На примере формирования законов движения частииы по шероховатых нелинейчатых поверхностях в среде компьютерной алгебры Maple показана возможность вообще не представлять последовательность громоздких аналитических преобразований. В этом случае пользователю модели исследования движения частищы по шероховатой поверхности достаточно только задавать исходные условия бросание частииы и формировать набор изучаемых траекторно-кинематических характеристик.

Ключевые слова: сопроводительный трехгранник, материальная точка, нелинейные поверхности, траектория движения 